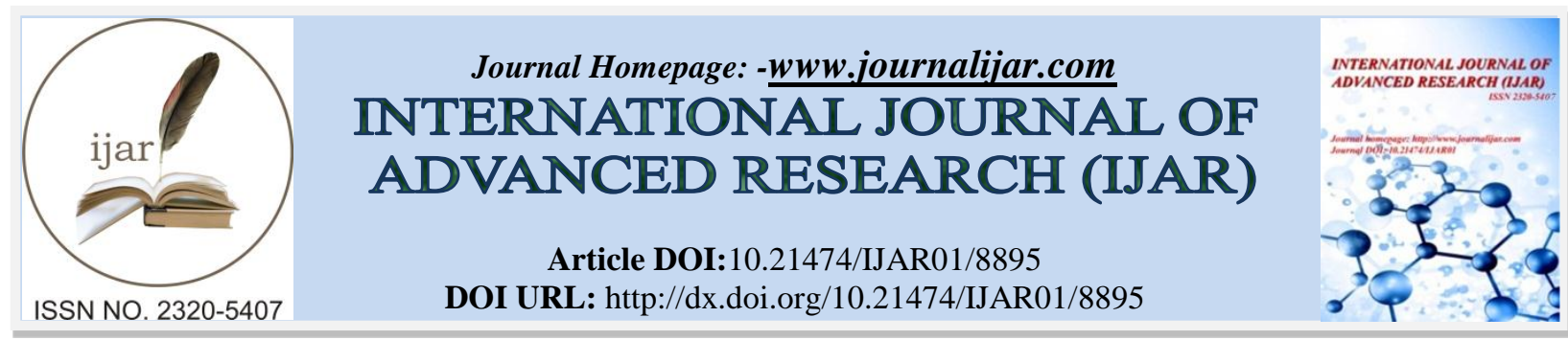

RESEARCH ARTICLE

\title{
CONTRIBUTIONS OF INVESTIGATIVE TEACHING FOR UNDERSTANDING THE GREENHOUSE EFFECT IN THE FINAL GRADES OF ELEMENTARY SCHOOL.
}

\section{Gilvânia Luana da Rocha Silva Neves ${ }^{1}$, Tamiris Alves Rocha ${ }^{2}$, Dayane de Melo Barros ${ }^{3}$, Danielle Feijó de Moura $^{3}$, Patrícia Luana Barbosa da Silva Ribeiro ${ }^{4}$, Isalia Amara Da Silva ${ }^{5}$, Marllyn Marques da Silva ${ }^{3}$, Gerliny Bezerra de Oliveira ${ }^{3}$ and Kelma Sirleide de Souza ${ }^{2}$.}

1. Especialista em Ensino de Ciências - Instituto Federal de Pernambuco - Pernambuco.

2. Doutora em Ciências Biológicas - Universidade Federal de Pernambuco - Pernambuco.

3. Mestre em Saúde Humana e Meio Ambiente - Centro Acadêmico de Vitória, Universidade Federal de Pernambuco, CAV/UFPE - Pernambuco.

4. Especialista em Fisiologia Humana Aplicada a Saúde - Universidade Estácio de Sá - Pernambuco.

5. Especialista em Educação Inclusiva - Faculdade Anchieta - Pernambuco.

\section{Manuscript Info}

Manuscript History

Received: 12 February 2019

Final Accepted: 14 March 2019

Key words:-

greenhouse effect, investigative activity, learning.
Published: April 2019

\section{Abstract}

The demand for new methodological tools has become increasingly indispensable, since the use of traditional education is gradually less efficient in classrooms. In this conception, investigative teaching is one of the tools that can be used in the teaching-learning process to enrich and broaden student understanding during this process. In science, one of the topics covered in the classroom is the Greenhouse Effect, which has been shown to be a complex approach for students. In this context, the present study aimed to identify the contributions of teaching and research in science classes during the development of the theme "Greenhouse Effect", aiming to analyze the students' learning about the demystification of said harmful effects that this phenomenon can cause to the environment . For this, a qualitative analysis was carried out from the research activity and a questionnaire on the subject was then applied to the students. The questionnaires were divided into pre-test and post-test. The results obtained were analyzed and expressed in percentage, verifying the importance of research teaching in learning. Therefore, it can be verified that the research proposal contributes to and assists students in understanding both the content covered (greenhouse effect) and science classes in general.

Copy Right, IJAR, 2019,. All rights reserved.

\section{Introduction:-}

The use of lectures, in which the teacher is the active subject in the teaching-learning process and the student, the recipient of information, is characteristic of traditional teaching. According to Santos (2011) in disciplines that use only the traditional method, the classes are centered on the teacher, which defines what will be the contents taught to the students, as well as the organization of how the teaching-learning process will be carried out.

Corresponding Author:-Tamiris Rocha.

Address:-Doutora em Ciências Biológicas - Universidade Federal de Pernambuco. 
However, this traditional teaching practice has shown less resolving to the demands of students in the classroom. In this sense, during the practice of teaching some teachers tend to look for different methodologies to use in elementary and high school classes. Therefore, the search for innovative classes becomes constant with the goal of becoming more attractive since, at present, the traditional method of teaching has been challenged due to the needs of the students, who feel difficulties regarding the application of theories exposed in the classroom class (WEINTRAUB, HAWLITSCHEK and JO ÃO, 2011).

In this perspective, the investigative teaching is a didactic strategy that the teacher can use in its practice of the school routine. Through it are stimulated scientific attitudes such as: identification of problems, elaboration of hypotheses, planning of tests and experiments, recording and collecting data, reflection and validation of hypotheses and elaboration of explanatory models. In the research activity the student must design and identify something interesting to be solved, but, if they must propose automatic procedures to arrive at a solution (OLIVEIRA, 2010). In this way, the student has the opportunity to construct his critical thinking, to develop his thinking and to become an active student, not just an assimilator of information given by the teacher.

In the teaching of the science discipline, one of the contents addressed in elementary education is air pollution and inserted in this context has a sub-theme that is the Greenhouse Effect. This is generally considered as a phenomenon that causes harm to the planet earth, however, life on earth is only possible because of this effect. Because it is an issue that can interfere with the planet's environmental conditions and human life, it is important to have a correct understanding of its size, causes and consequences (XAVIER and KER, 2004). Therefore, the insertion of investigative teaching as a tool to develop a student's critical sense and clarify some misconceptions about the subject matter becomes relevant.

Increasingly, it is necessary to seek new teaching methodologies to improve the teaching-learning process and to stimulate the attention of the student to the space of the classroom. In this way, research teaching can be cited as one of the tools that can be used within the classroom to further enrich this process. Therefore, this study aims to identify the contributions of research teaching in science classes during the development of the theme "Greenhouse Effect", for the students' learning about the demystification of said harmful effects that this phenomenon can cause to the environment. It was also possible to verify the previous knowledge of the students about the function of the natural phenomenon "Greenhouse Effect" in the planet earth through a subjective questionnaire, as well as to perceive through the optics of the students the advantages of using investigative teaching as a didactic strategy in learning.

\section{Theoretical foundation}

The Greenhouse Effect represents a natural phenomenon in which the radiation coming from the sun is converted and reflected in the formation of infrared radiation to the atmosphere and still results in the accumulation of gases in the atmosphere that when absorbing this radiation ends up emitting heat. However, because of this phenomenon, there is life on earth, as it is estimated that the planet would average about $30{ }^{\circ} \mathrm{C}$ below temperature. According to Xavier and Ker (2004), the "vital function" that this phenomenon exerts on the planet is still inadequately propagated "Environmental issues have been widely discussed in recent times. One of the topics most covered is the Greenhouse Effect. Its presence is constant in magazines and newspapers, which is good because it is an important ecological problem. Todavia essa popularização tem sido acompanhada por abordagens com alta incidência de equívocos. However, this popularization has been accompanied by approaches with a high incidence of misconceptions. The great power of dissemination of information through the media ends up favoring the crystallization of conceptual errors with the population.

Because it is a very important issue related to the environment, it is necessary to pay more attention to how the subject will be disclosed to the students. According to XAVIER and KER, 2004, pp. 325-349:

"Deterministic catastrophic approaches are very common and misleading. They generally conclude that we are facing an evil effect, when in fact it is important for the development of the biosphere and what brings with it are the changes observed in its pattern. Even if these approaches aim to alert the possible evolution of the problem, they are non-descriptive and reflect an attempt to manipulate the target audience".

In an attempt to more successfully address this content in the classroom, it is possible to use diversified methodologies, such as investigative teaching. According to WILSEK and TOSIN (2009) research teaching is an innovative tool that establishes a change within the classroom. 
"Teaching Science by Research means innovating, shifting the focus of class dynamics from a mere transmission of content. And, shifting the focus, other attitudes became necessary, as a new direction in the feel, to act, to reflect on the methodological strategies used in the room and also, to review the theoretical assumptions that guided my professional practice as well as the planning of the work".

From the investigative activity the student begins to produce his own knowledge and reveal more autonomy within the classroom. According to Azevedo (2004) "A research activity must start from a problematizing situation should lead the student to reflect, discuss, explain, report, finally, that he begins to produce his own knowledge through the interaction between thinking, feeling and doing. In this perspective, the learning of procedures and attitudes becomes, as part of the learning process, as important as the learning of concepts and / or content".

\section{Methodology:-}

The study is a qualitative research developed in the discipline of Science from 3 meetings proposed in the final grades of elementary school. The chosen theme was "Greenhouse Effect Phenomenon" included in the content Air Pollution. At the first meeting a pre-test was applied about the studied effect. The pre-test was the first instrument used, since it was necessary to recognize the previous knowledge of the students on the subject. The questionnaire was applied to 15 students. This questionnaire was composed of 04 questions.

After this pre-test was observed the students' lack of knowledge about the Greenhouse Effect Phenomenon, since this phenomenon is incorrectly stigmatized.

Then the group was divided into 3 groups, where each group performed the experiment that simulates the greenhouse effect, developing the following steps: 1) Cover the inside of the box with aluminum foil; 2) Place a glass of water inside the box; 3) Cover the box with plastic film; 4) Put a second glass and box under the sunlight; 5) Between 10-15 minutes later, open the box and check with the thermometer which of the two cups had the most heated water.

During the activity interval, these groups of students were asked to formulate hypotheses of what could happen in the experiment and its possible reasons. The entire process was conducted by the mediator teacher. After the end of the experiment the students evaluated whether their hypotheses could be confirmed or not.

At the end of the process, a post-questionnaire containing 4 subjective questions was submitted to analyze the advantages of the teaching of investigative teaching as a didactic strategy, as well as the students' understanding of the greenhouse effect.

\section{Results and Discussion:-}

The average age of the students was between 11 and 14 years old. In the question about knowledge about the term greenhouse effect (Figure 1), it was observed that $40 \%$ of students stated that they knew about this phenomenon, while $46 \%$ answered that they did not know, and 14\% affirmed their doubts about the question. The absence of knowledge about this phenomenon was noticed, although the content was approached in elementary school I.

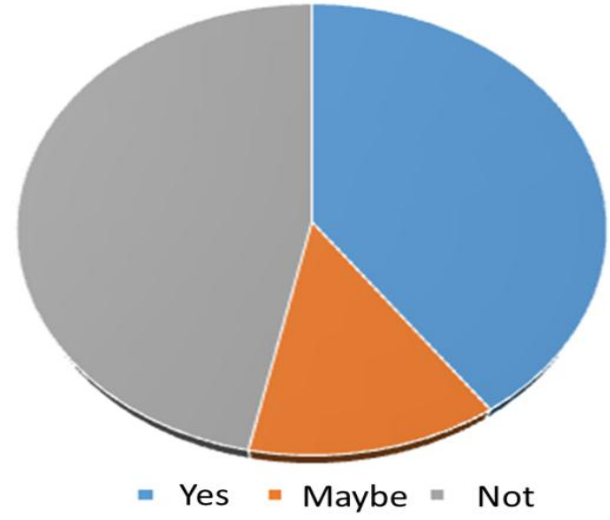

Figure 1:-Have you ever heard of Greenhouse Effect? 
In the question concerning the meaning of the greenhouse effect (Figure 2), several definitions of this phenomenon were obtained, and all showed difficulty in explaining the real meaning. We developed categories for the analysis of the students' responses, the categories created and respective amounts of responses of the participants were: students who did not know how to respond (46\%), students who were confused when answering (14\%) and students who answered correctly ( $40 \%)$.

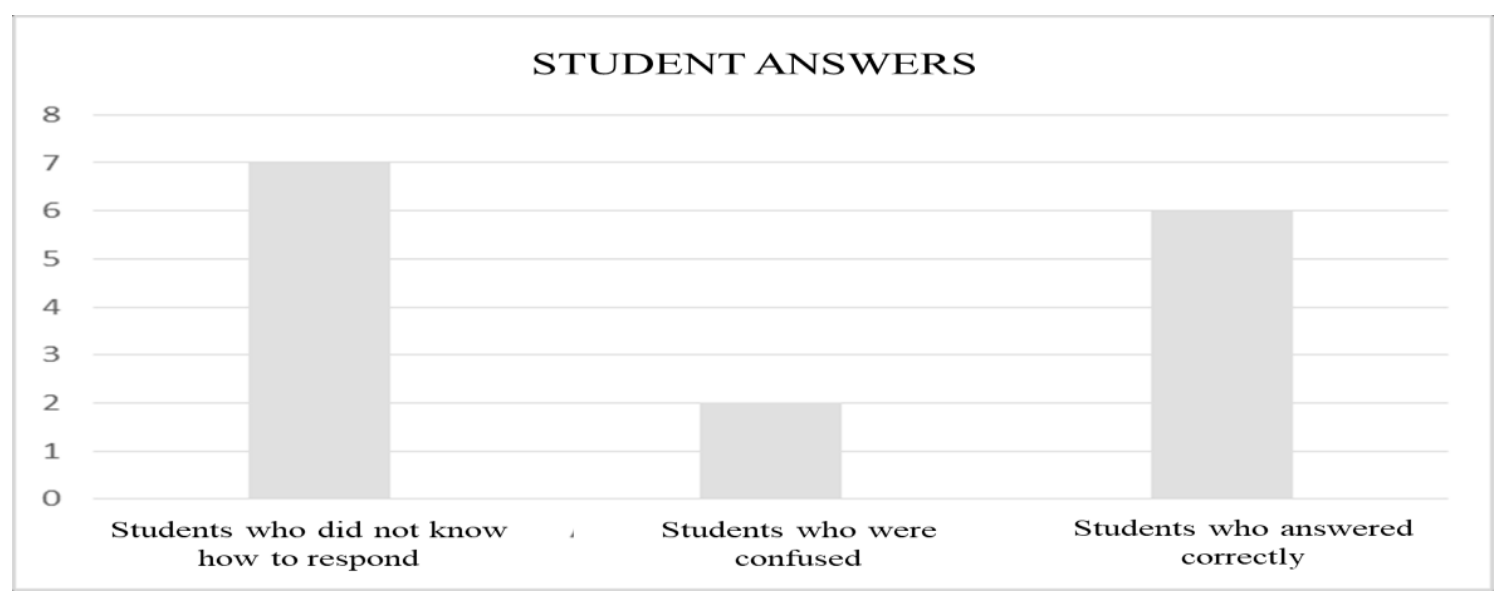

Figure 2:-Sow is the Greenhouse Effect?

It was noticeable, the fragility of knowledge about the content although it has been experienced in the previous series of the same discipline as previously reported.

When asked: "By your knowledge about this phenomenon, do you believe that it can cause harm to the environment?" The results were: students who were unable to answer (34\%), students who have confirmed that this phenomenon can cause environmental damage (46\%) and students who disagreed as to the possible environments losses of this phenomenon on the environment (20\%).

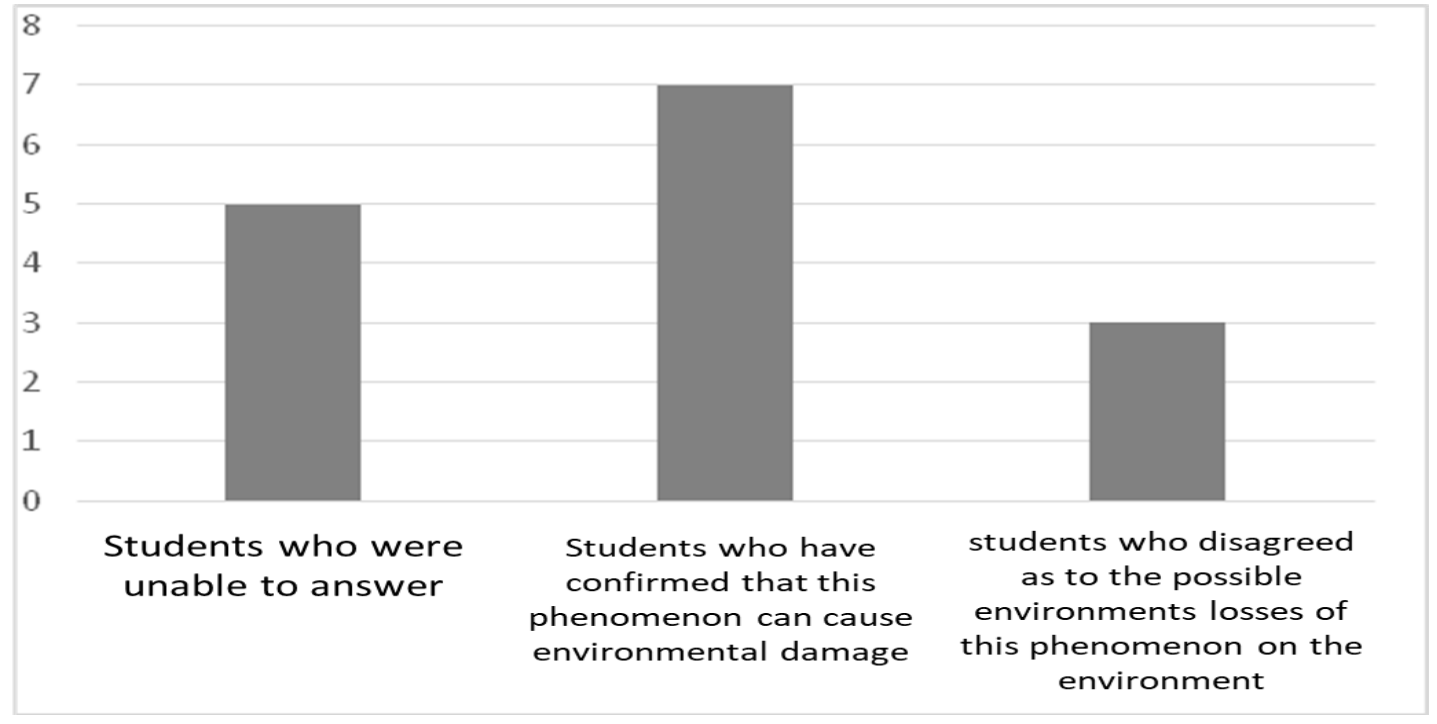

Figure 3:-By your knowledge of this phenomenon, do you believe that it can cause harm to the environment?

A significant number of students believe that this phenomenon has a negative effect on the environment, which reinforces the idea of XAVIER and KER (2004) that this phenomenon ends up being presented in an inadequate way, without at least reporting that the same is essential for life on earth. It is also noticeable a significant number of students who do not know this phenomenon, evidencing the importance of addressing this content in the initial grades of elementary school.

During the investigative activity, the groups of students formulated their hypothesis before the experiment. Three hypotheses were obtained, the first group formulated the following 
hypothesis: "The water that is outside the box will heat up faster", while group 2 hypothesized that "The glass inside the box will heat up faster, because the sun hits the foil and back more cannot leave due to the role of film, "group 3 reported that "The water of the glass inside the box will heat up faster due to aluminum foil". Investigative teaching brings this autonomy to the student, causing him to produce hypotheses, as Azevedo (2004) himself reports, that through investigative teaching the student can produce his own knowledge, revealing independence to interpret phenomena that happen around him.

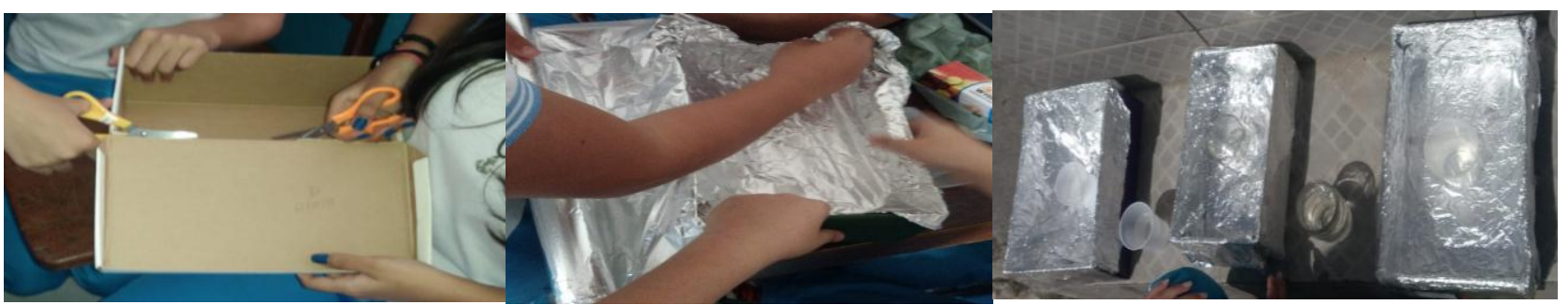

Figure 4:-Images related to the production and execution of the Investigative Activity

The post-test evaluated the advantages of using the didactic strategy of investigative teaching in learning about the function of the Greenhouse Effect. the following question was made: "Now what is greenhouse effect?", the responses were categorized as follows: do not know answer (6\%), if confused (20\%) and answered properly (74\%). Noting that there was an advance in the students' knowledge about this topic. This result strengthens the use of investigative activities in science education, since the students demonstrated an understanding of the subject matter.

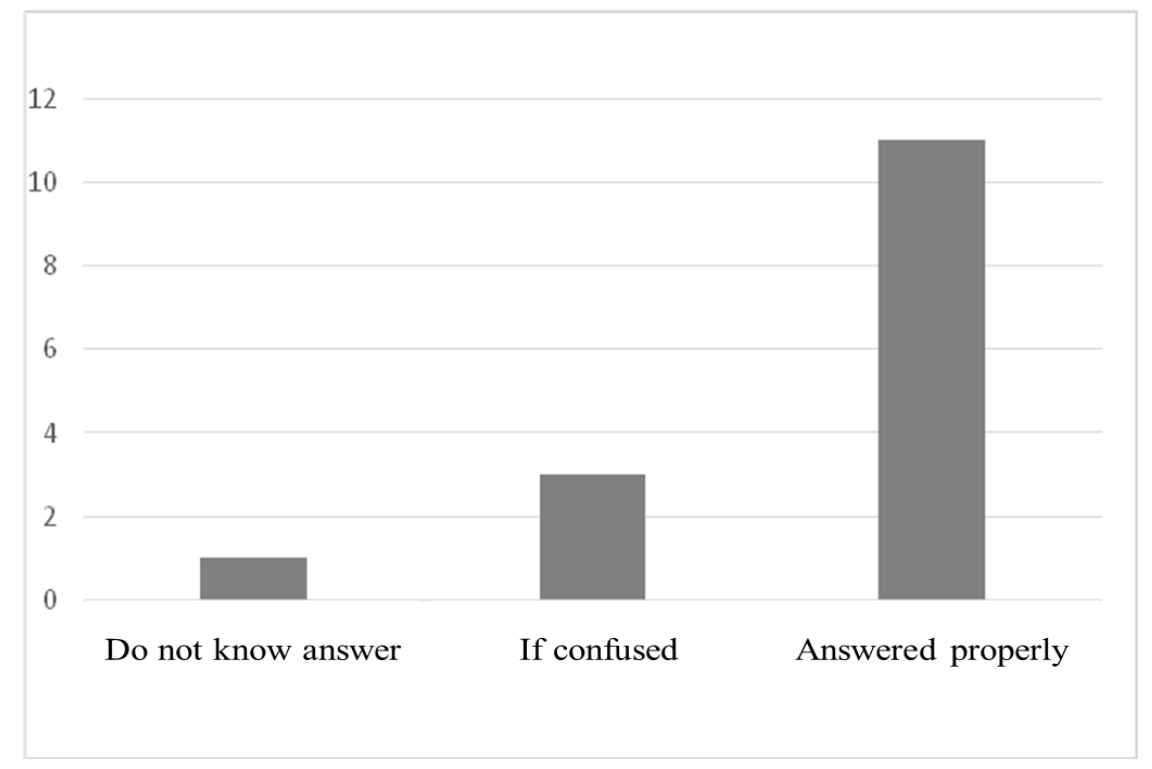

Figure 5:-And now what is Greenhouse Effect?

In the second question, it was asked: "How does the Greenhouse Effect affect temperature and life on earth?". The students showed slight difficulties in answering this question where $74 \%$ of students knew how to respond to this questioning and only $26 \%$ did not know how to respond. 


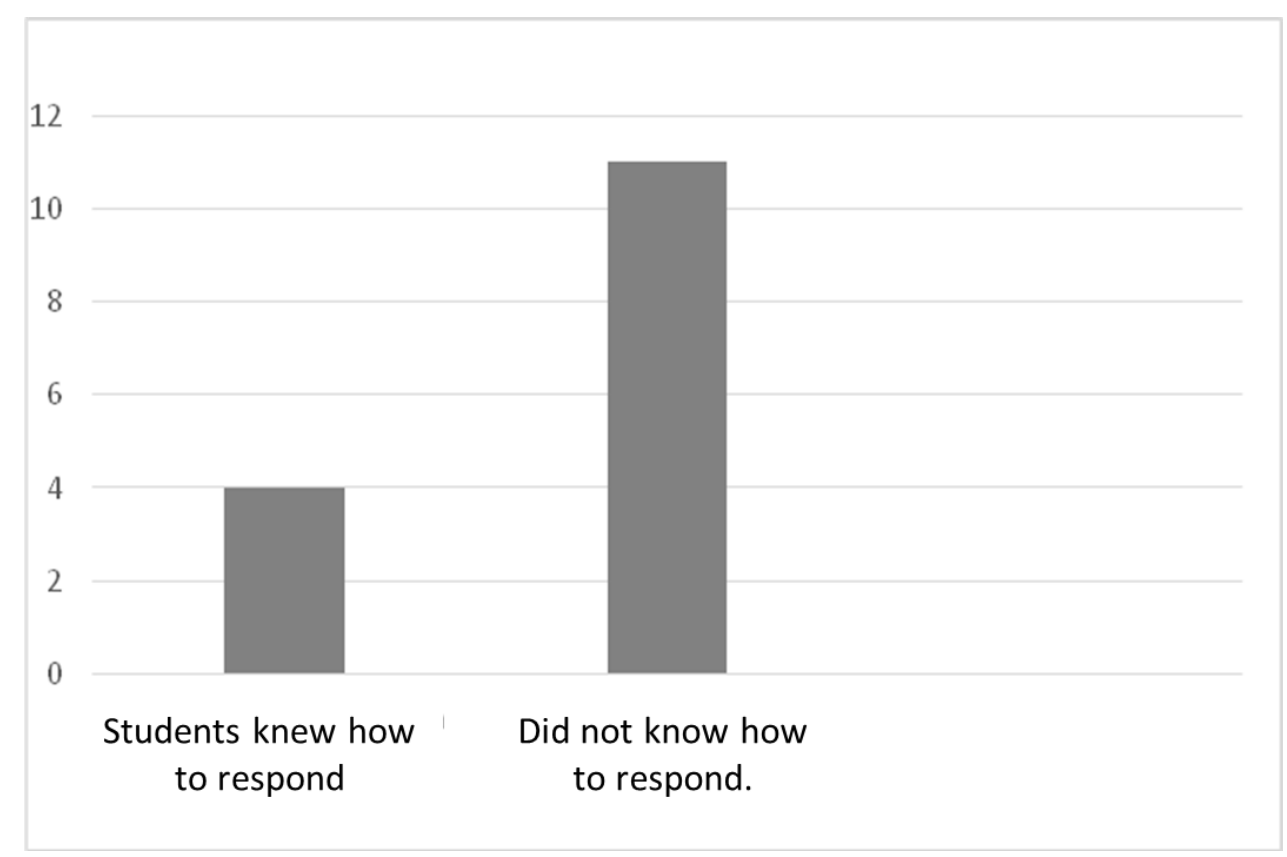

Figure 6:-Response of the second post-test question

Faced with the questioning: "After the investigative activity, you can affirm that the greenhouse effect is a phenomenon harmful to the environment?". The results were significant, since $95 \%$ of the students answered that the Greenhouse Effect is a beneficial phenomenon, whereas only $6 \%$ of the students did not know how to respond.

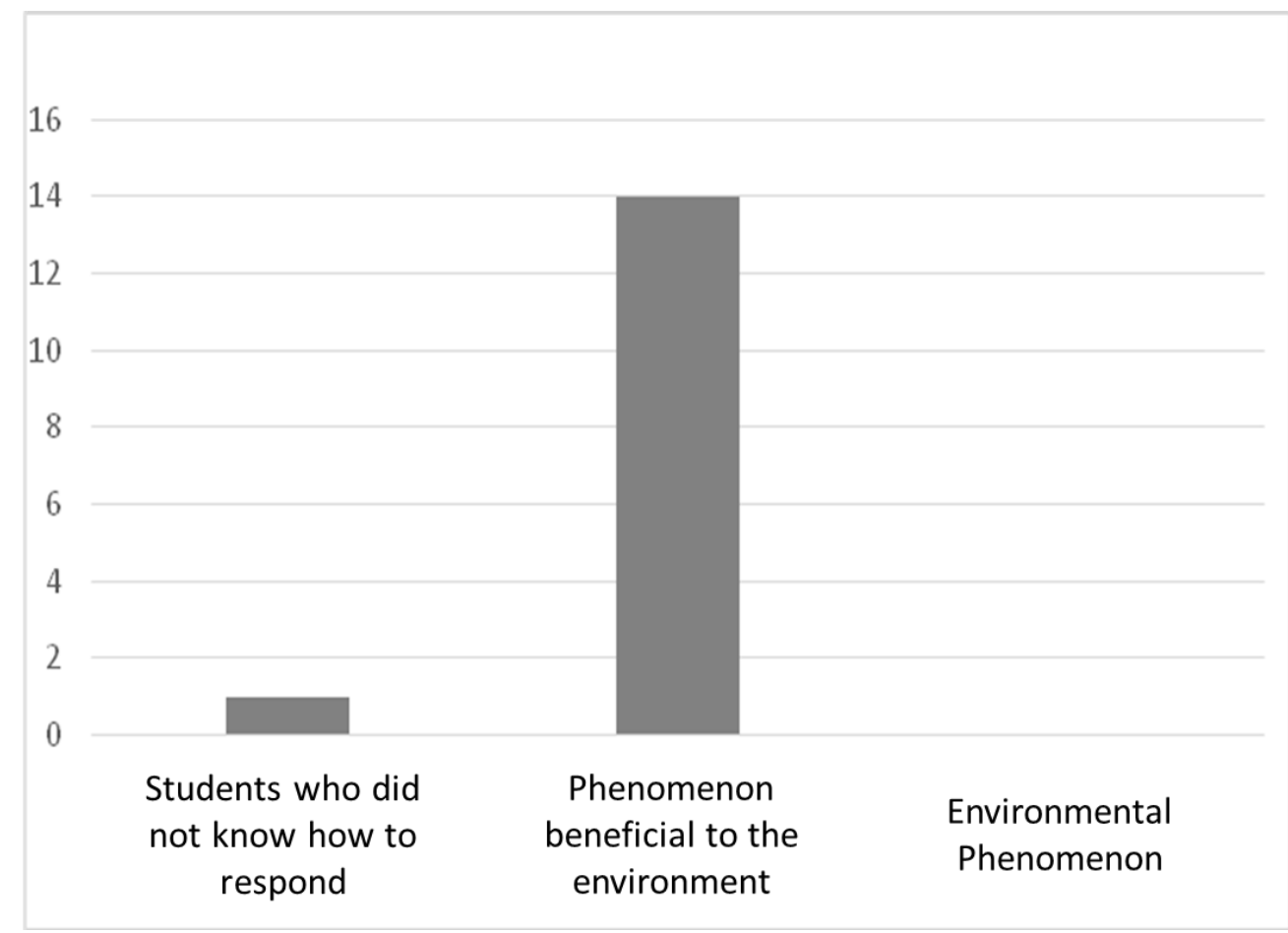

Figure 7:-After the investigative activity, can you say that the greenhouse effect is a beneficial or harmful phenomenon to the environment?

It is worth mentioning that, during the course of the class, there was a great capacity, commitment and involvement of the students to carry out the activity. Students actively participated in teaching practice, suggesting and discussing 
content. In relation to the educator, it assumed the role of mediator, thus allowing the student to act in a more integrated way in the teaching-learning process.

\section{Conclusions:-}

The methodological tool used in this study for the development of the "Greenhouse Effect" content helped the students to understand how this phenomenon works on the planet, correcting some erroneous concepts that are attributed to the hormone, either due to the lack of adequate information or by erroneous interpretations. It was also verified that the use of strategies different from the traditional ones can result in a construction of knowledge that goes beyond a simple transmission of information, since this type of practice potentiates and stimulates the student's reasoning, besides encouraging the interest for science.

\section{References:-}

1. AZEVEDO, M. C. P. S. Ensino por investigação: problematizando as atividades em sala de aula. In: CARVALHO, A. M. P. (Org.). Ensino de ciências: unindo a pesquisa e a prática. São Paulo: Pioneira Thomson Learning, p. 19-33, 2004.

2. OLIVEIRA, J. R. S. Contribuições e abordagens das atividades experimentais no ensino de ciências: reunindo elementos para prática de docentes. Acta Scientiae, v.12, n.1, p.139-153, 2010.

3. SANTOS, W. S. Organização Curricular Baseada em Competência na Educação Médica. Revista Brasileira de Educação Médica, v. 35, n. 1, p. 86-92, jan./mar. 2011.

4. XAVIER, M. E. R.; KERR, A. S. Análise do efeito estufa em textos paradidáticos e periódicos jornalísticos. Cad. Bras. Ens. Fís., v. 21, n. 3: p. 325-349, dez 2004.

5. WILSEK, M. A. G.; TOSIN, J. A. P. Ensinar e aprender ciências no ensino fundamental com atividades investigativas através da resolução de problemas. Portal da Educação do Estado do Paraná, p. 1686-8, 2009.

6. WEINTRAUB, M.; HAWLITSCHEK, P.; JOÃO, S. M. A. Jogo educacional sobre avaliação em fisioterapia: uma nova abordagem acadêmica. Fisioterapia e Pesquisa, v. 18, n. 3, p. 280-286, 2011. 